33-34 | 2003

Sortir de la nuit

Jean-Luc Lambert

\title{
Chapitre II. Noces chamaniques
}

Chapter II. Shamanic wedding

Jean-Luc Lambert

\section{(2) OpenEdition}

Journals

Édition électronique

URL : https://journals.openedition.org/emscat/1372

DOI : 10.4000/emscat.1372

ISSN : 2101-0013

Éditeur

Centre d'Etudes Mongoles \& Sibériennes / École Pratique des Hautes Études

Édition imprimée

Date de publication : 2 décembre 2003

Pagination : 161-216

ISSN : 0766-5075

Référence électronique

Jean-Luc Lambert, « Chapitre II. Noces chamaniques », Études mongoles et sibériennes, centrasiatiques et tibétaines [En ligne], 33-34 | 2003, mis en ligne le 17 mars 2009, consulté le 13 juillet 2021. URL http://journals.openedition.org/emscat/1372 ; DOI : https://doi.org/10.4000/emscat.1372

Ce document a été généré automatiquement le 13 juillet 2021.

(c) Tous droits réservés 


\title{
Chapitre II. Noces chamaniques
}

\author{
Chapter II. Shamanic wedding
}

\author{
Jean-Luc Lambert
}

\section{RÉSUMÉS}

La question d'un éventuel mariage du chamane nganassane est posée. Car, d'une part, la canne en fer est l'attribut majeur du marieur nganassane - et, sous des formes proches, des marieurs de tous les groupes samoyèdes et ob-ougriens - qui, lors des demandes en mariage, effectue un déplacement comparable à celui du chamane lors de la fête. Car, d'autre part, une analyse des lanières rituelles utilisées pour la fête montre qu'elles renvoient à des « fils de vie » liés au soleil et à la lune, astres que les mythes associent à la fête annuelle et au mariage. Enfin, toute une série de récits nganassanes d'origine russe mettent en scène une fille du soleil (la princesse des contes européens) apportant chaleur et lumière au héros qui l'épouse. Comme les chamanes nganassanes la comptent parmi leurs esprits-auxiliaires, la fête annuelle célébrerait un mariage entre chamane et fille du soleil. Le rite ne doit toutefois pas être organisé en temps d'épidémies, car ce serait alors la femme-variole qui serait épousée par le chamane, ce qui entraînerait mort et désolation.

The question of a possible marriage of the Nganasan shaman is raised. On the one hand an iron cane is the major attribute of a Nganasan matchmaker (and also, in related forms, of all Samoyed and Ob-ugrian matchmakers), who when asking in marriage travels in the same way as the shaman does during the festival. On the other hand an analysis of the ritual thongs used during the festival shows that they refer to "life-threads" connected to the sun and the moon, which Nganasan myths associate with the annual festival and with marriage. Finally a whole series of Nganasan tales of Russian origin presents a sun daughter (the equivalent of the princess in European tales) bringing heat and light to the hero of the tale who marries her. As the Nganasan shamans count her among their helping spirits, the annual festival may celebrate a marriage 
between the shaman and the sun daughter. The ritual is not however celebrated during epidemics, because then the shaman would be marrying the smallpox woman, which would lead to death and desolation.

\section{INDEX}

nomsmotscles Enets, Nenets, Nganasan, Samoyède

Thèmes : chamanisme, fêtes, littérature, mythologie, nomadisme, organisation sociale, parenté, religion, représentations

Index géographique : Arctique, Russie, Sibérie occidentale, Sibérie septentrionale, Taïmyr, Toundra

Mots-clés : alliance, chamane, mythe, rituel

Keywords : marriage, myth, ritual, shaman

\section{AUTEUR}

\section{JEAN-LUC LAMBERT}

